lead taken out of the plant by the workers on their clothes.

A number of recommendations are made: these include emphasizing once more that top management carry the responsibility for the protection of the health of workers; the importance of industrial hygiene and monitoring of the atmosphere, and the desirability of close co-operation of those concerned with the works medical officer; the education of the workers; and ensuring a flow of information to both workers and management about environmental contamination.

Finally, the committee highlight the need for research into a variety of problems ranging from a study of the relationship of particle size to lead absorption, the need for more knowledge about the significance of minor alterations in metabolism, and the accumulation of body burdens of lead, to the possible long-term effects of lead absorption in the absence of symptoms of poisoning.

The committee should be congratulated on producing the report within four months of its appointment and for the clear-cut assessment made of the unfortunate circumstances at the Avonmouth smelter. The report should serve to crystallize a number of problems which have been a cause of anxiety to those concerned with the protection of persons exposed to lead in their work, in particular, the emphasis on the importance of distinguishing 'lead absorption' from 'lead poisoning' and its evaluation by reference to blood lead levels. There has been a need for some time to clarify in an official document the difference between poisoning and absorption and to specify the criteria which should be used in the assessment of persons who have clearly absorbed an excessive quantity of lead in their work.

\section{References}

British Medical Journal (1968) Diagnosis of inorganic lead poisoning: A statement. 4, 501.

Report of a Committee under the Chairmanship of Sir Brian Windeyer appointed to inquire into Lead Poisonings at the RTZ Smelter at Avonmouth. (1972). Cmnd. 5042. HMSO, London.

Received for publication January 27, 1973. Accepted for publication February 7, 1973.

\title{
Long-term occupational exposure to the insecticides aldrin dieldrin, endrin, and telodrin
}

\author{
J.P. J. VERSTEEG ${ }^{1}$ and K. W. JAGER \\ Shell Internationale Research Maatschappij N.V., The Hague, The Netherlands
}

\begin{abstract}
Versteeg, J. P. J. and Jager, K. W. (1973). British Journal of Industrial Medicine, 30, 201-202. Long-term occupational exposure to the insecticides aldrin, dieldrin, endrin, and telodrin. A medical survey of 233 long-term insecticide workers has previously been published. Fifty-two of them had left employment at the time of the original publication. All members of this group could be traced. No unexpected adverse effects on health were found. Their disease pattern and general well-being were not different from those in the original group.
\end{abstract}

\footnotetext{
${ }^{1}$ Formerly chief medical officer Shell Nederland Raffinaderij

N.V. and Shell Nederland Chemie N.V., Rotterdam.
} 
Aldrin and dieldrin have been manufactured and formulated since 1954, and endrin since 1957, in a plant of Shell Nederland Chemie N.V. at PernisRotterdam. Telodrin was handled only between 1958 and 1965.

Several doctors from the plant industrial medical department have previously reported on the health condition of the workers involved in handling these insecticides in this plant (Hoogendam, Versteeg, and de Vlieger, 1962 and 1965; Jager, 1970). From the latter study the following conclusions with regard to these insecticides could be drawn:

Occupational exposure for periods of up to 15 years (now up to $17 \frac{1}{2}$ years) at times even at toxic doses did not result in any persistent adverse effect on the health of these workers as far as could be demonstrated by the parameters which were used. These included, apart from general physical examination, miniature chest radiograph, electro-encephalogram, routine urinalysis; a blood examination: $\mathrm{Hb}, \mathrm{WBC}, \mathrm{RBC}$, haematocrit, MCV, SRE, plasma ChE, SGPT, as well as a blood chemistry profile (Auto-Analyzer SMA 12/60) consisting of 12 biochemical tests: total protein, albumin, alkaline phosphatase, LDH, SGOT, inorganic phosphate, cholesterol, glucose, uric acid, bilirubin, calcium, and urea nitrogen.

The patterns and rates of absenteeism due to disease and accident of our insecticide workers are similar to those of operators of the same average age in other chemical plants.

All signs and symptoms of intoxication were fully reversible, in the case of endrin within a few days, with aldrin and dieldrin within weeks, and in the case of telodrin within six months.

With all the parameters used, and the addition of parameters of liver microsomal enzyme induction (the pp'DDE levels in whole blood and the ratio of excretion of $6-\beta-\mathrm{OH}$-cortisol in urine compared to that of 17-OH-corticosteroids), a no-effect level in man was established for aldrin and dieldrin above a minimum dieldrin level in blood of $0.105 \mu \mathrm{g} / \mathrm{ml}$.

The present exposures of the general population to aldrin and dieldrin in the United Kingdom and the United States of America (and probably also in most of western Europe) result in blood levels which are 175 times lower than the established no-effect level in occupationally exposed men (Jager, 1970). This exposure may thus be regarded as safe, as far as can be demonstrated by the parameters used in this study.

In Jager's (1970) study the data of a group of 233 workers with occupational insecticide exposures of more than four years' duration were evaluated. For 52 workers in this group no follow-up data could be given at that time as they had left the company. Only their reasons for leaving could be given (p. 129). At the time of that study two workers out of the larger group of 233 had died, one a 46-year-old man from ischaemic heart disease, and the other a 53-year-old man from carcinoma of the stomach.

As a supplement to this still continuing study we wanted to obtain information on the present state of health of this group of 52 'drop-outs' in order to check whether any unexpected adverse effects had escaped our attention. As some of these workers had moved to other parts of the country or abroad it was not possible to see them all personally, so that in such cases data were obtained by means of a questionnaire.

No medical examination could be done nor any laboratory testing. However, it was possible to locate all 52 workers and obtain information on their present health condition.

The average occupational insecticide exposure in this group of workers was $6 \cdot 6$ (range $4 \cdot 0-12 \cdot 3$ ) years. The average time that had elapsed since the end of the exposure was, at the time of this survey, 7.4 (range 4.5-16) years. The average age of this group at the time of the survey was $47 \cdot 4$ (range 29-72) years.

In the four-and-a-half years since the 1970 report, only one man had died in the group now under study. This was a man 69 years of age who died as a passenger in a car accident. A man with hyperthyroidism, who was mentioned in the previous report, awaits surgical treatment; another man has suffered from mild acute pancreatitis. None of the other 47 workers had suffered from other than the usual minor illnesses since the exposure was discontinued. Neither hepatic disease nor epileptiform convulsions occurred. No new cases of malignant disease had developed in this group of former insecticide workers.

In conclusion it may be stated that the result of this limited but complementary survey of drop-out former insecticide workers is consistent with the above conclusions made for the workers who remained under our own medical supervision.

The authors wish to express their appreciation to the Industrial Medical Department of Shell Nederland Raffinaderij N.V. and Shell Nederland Chemie N.V. (head Dr. J. H. Becking) for their ready and helpful co. operation with this survey and to record the cooperative and helpful attitude of the workers surveyed.

\section{References}

Hoogendam, I., Versteeg, J. P. J., and de Vlieger, M. (1962). Electroencephalograms in insecticide toxicity. Archives of Environmental Health, 4, 86-94.

- $-\ldots,-(1965)$. Nine years toxicity control in insecticide plants. Archives of Environmental Health, 10, 441-448.

Jager, K. W. (1970). Aldrin, Dieldrin, Endrin and TelodrinAn Epidemiological and Toxicological Study of Long-term Occupational Exposure. Elsevier Publishing Company, Amsterdam.

Received for publication September 11, 1972.

Accepted for publication October 27, 1972. 